\title{
Canal de Mensagens de Trânsito
}

Telecommunication Sector Update

Traffic Message Channel (TMC)

Submetido(submitted): 17 de novembro de 2009

Parecer(revised): 3 de dezembro de 2009

Aceito(accepted): 14 de dezembro de 2009

Egon Cervieri Guterres*

Informe setorial

Atualizado até outubro de 2009

\section{O trânsito e o Canal de Mensagens de Trânsito: introdução}

O Canal de Mensagens de Trânsito (Traffic Message Channel - TMC) é uma padronização internacional para a distribuição de informações (conteúdo) sobre a situação do trânsito urbano local e inter-regional, em tempo real, de forma eletrônica e diretamente aos motoristas. Traz para os cidadãos, em mensagens eletrônicas simples e acessíveis, informações sobre congestionamentos, acidentes, obras na pista, problemas climáticos (alagamentos, asfalto escorregadio, nevoeiro...) e desvios de rota, além de muitos outros eventos de trânsito, oferecendo, em linguagem padronizada de fácil compreensão, a descrição do incidente, área de efeito, duração esperada e, quando possível, caminhos alternativos para evitá-lo.

Como solução tecnológica, é certamente das mais úteis, pois alveja um dos problemas mais críticos das grandes (e médias) metrópoles brasileiras, o trânsito cada vez mais caótico:

Os grandes aglomerados urbanos brasileiros amargam congestionamentos cada vez maiores. De acordo com dados do Departamento Nacional de Trânsito (Denatran), circulam pelas ruas e

*Graduado em Engenharia Mecatrônica e graduando em Direito pela Universidade de Brasília. Especialista em Regulação de Serviços Públicos de Telecomunicações da Agência Nacional de Telecomunicações (ANATEL) e Membro Pesquisador do Grupo de Estudos em Direito das Telecomunicações (GETEL/UnB). Contato: egon@anatel.gov.br. 
estradas do país cerca de 45 milhões de veículos, entre eles automóveis, caminhões, motocicletas, tratores e ônibus. A região Sudeste concentra 24 milhões de veículos, e desses, 6 milhões transitam nos 17.000 quilômetros de vias da cidade de São Paulo. Além da capital paulista, Rio de Janeiro, Brasília e Recife são algumas das capitais que não suportam mais os freqüentes engarrafamentos. $\mathrm{O}$ trânsito excessivo nas grandes cidades provoca conseqüências muito mais graves do que os atrasos e transtornos enfrentados diariamente pelos motoristas. Os congestionamentos custam muito dinheiro, prejudicam a saúde da população e atrapalham o crescimento do país. Portanto, resolver (ou amenizar) o problema não é apenas uma questão de conforto e bem estar - é também um importante incentivo ao desenvolvimento econômico e social.

(...)

A Secretaria de Estado dos Transportes Metropolitanos estima que as perdas financeiras com acidentes de trânsito, poluição e engarrafamentos em São Paulo sejam de 4,1 bilhões de reais por ano. Já o Instituto de Estudos Avançados da USP calcula perdas diárias de 11 milhões de reais com tempo e combustível nos congestionamentos. 0 estudo considera a média de 80 quilômetros de lentidão por dia, com picos de 200 quilômetros. No total, os custos anuais chegariam a 3,3 bilhões. As soma do tempo perdido pelas pessoas no trânsito atinge a média de 240.000 horas anuais. São desperdiçados cerca de 200 milhões de litros de gasolina e álcool e 4 milhões de litros de diesel por ano nos engarrafamentos na cidade. A paralisia do trânsito tem impacto na economia como um todo. ${ }^{1}$ (VEJA.com) (grifei)

De imediato, o que o TMC faz é informar constantemente ao motorista a situação da via em que trafega, para que possa optar pelo melhor caminho, ou ao menos lhe dar uma previsão de tempo, caso já esteja preso no congestionamento. Também pode ser muito útil para o pedestre, para

${ }^{1}$ VEJA.com. O impacto do caos nas ruas. Disponível no sítio eletrônico: veja.abril.com.br. Acesso em: 18 de outubro de 2009. Nessa reportagem especial da coluna "Em profundidade" também há dados muito preocupantes dos efeitos dos congestionamentos para a saúde. Além dos problemas auditivos, os mais evidentes, as longas horas desperdiçadas no trânsito causam sensação de exaustão, enxaqueca, aumento da pressão arterial (aumentando o risco de enfarto e derrame), gastrite, úlcera, prisão de ventre e impotência.

Revista de Direito, Estado e Telecomunicações, v. 2, n. 1, p. 213-230 (2010)

DOI: https://doi.org/10.26512/lstr.v2i1.21689 
verificar se é mais vantajoso tomar um táxi ou seguir pelo metrô, por exemplo.

Mas é muito mais do que isso. Táxis, empresas de distribuição, logística e transporte coletivo urbano podem trabalhar de forma mais eficiente, e polícias, bombeiros e ambulâncias também, principalmente nos momentos mais críticos. E os centros de informação e controle de trânsito, secretarias de segurança pública, de obras e de transportes certamente encontrarão grande valor no volume de dados que o sistema como um todo integra, facilitando a administração do trânsito e o planejamento de vias, sistemas de transporte e outras obras públicas.

Um canal de comunicação direta com os motoristas abre todo um novo panorama dinâmico e interativo no compreender e administrar o trânsito. ${ }^{2}$ Pode-se, por exemplo, enviar uma mensagem para que os transeuntes de determinada via pública liberem a faixa da esquerda para passagem dos veículos de socorro pois houve um grande incêndio no centro da cidade. As possibilidades são muitas...

O objetivo neste pequeno diálogo (o primeiro de muitos, esperamos) é discutir a implantação do TMC radiotransmitido por meio do canal secundário de dados (padrão RDS) das emissoras de FM (e outros meios, posteriormente), para que seja recebido e exibido no visor do receptor de rádio $\mathrm{FM}$, ou ainda interpretado pelos navegadores de GPS compatíveis e apresentado graficamente por alertas e diferentes esquemas de cores para as vias afetadas. Apresentamos brevemente em seguida o funcionamento do sistema e os seus recursos mais básicos.

Também é rapidamente abordada a situação da tecnologia RDS-TMC em diversos lugares do mundo e as diferentes formas de exploração comercial (e/ou estatal) que adotam. Além disso, discute-se a possibilidade de uma solução nacional híbrida por parceria público-privada. Finalmente, são abordados os imensos desafios regulatórios que a implantação de tal sistema representa.

${ }^{2}$ Quanto à importância de tecnologias como o TMC na área dos Intelligent Transportation Systems (ITS), termo que engloba a integração entre telemática (telecomunicação mais informática para a prestação de serviços) e mobilidade, consultar "Aplicação do TMC no Processo Estratégico dos Sistemas Inteligentes de Transportes (ITS)" (CARVALHO, 2009).

Revista de Direito, Estado e Telecomunicações, v. 2, n. 1, p. 213-230 (2010) 


\section{Serviço de radiodifusão, serviço de telecomunicações e RDS-TMC}

O TMC é, como o próprio nome afirma, um 'canal de mensagens', no qual trafegam blocos de códigos padronizados. As mensagens são extremamente leves, sequências de uns poucos caracteres, simples códigos que referenciam locais, eventos e outras informações pré-estabelecidas em tabelas específicas. E sendo meros conjuntos de blocos de caracteres, são absolutamente independentes do meio e podem ser transmitidos por RDS/FM, web, satélite, TV Digital, 3G, WIMAX, MMDS ou o que mais se desejar.

Há, entretanto, uma série de fatores que fazem com que a rádio FM (ou melhor, o seu canal secundário [de dados]) seja o meio ideal para iniciar a implementação da tecnologia. Primeiro, as emissoras já cobrem integral e eficientemente as áreas urbanas (são mais de 1500 estações comerciais e educativas licenciadas e quase mais o mesmo tanto em licenciamento ${ }^{3}$ ). Segundo, o RDS é uma tecnologia conhecida e regulamentada ${ }^{4}$, com a qual os radiodifusores já estão habituados. Terceiro, para um sistema de recepção livre e aberta não há qualquer implicação técnica quanto à variação do número de sintonizadores (custo marginal e possibilidade de sobrecarga do sistema nula); assim, tanto faz se são 10 ou 10.000 receptores sintonizados o que não ocorre com outras redes de comunicação, que normalmente têm o número de canais (convencionais) limitado. Outro fator muito interessante é que o receptor fica completamente anônimo, preservando a privacidade do usuário caso ele assim deseje. $\mathrm{O}$ transmissor sequer sabe se há ou não receptores na área. Quarto, o público-alvo economicamente mais relevante das emissoras nos grandes centros urbanos é justamente aquele que está atrás do volante, desperdiçando cada vez mais do seu tempo e dinheiro nos

${ }^{3}$ Dados do Ministério das Comunicações. Disponível em: www.mc.gov.br. Acesso em: 18 de outubro de 2009.

${ }^{4}$ Anexo V, do Regulamento Técnico para Emissoras de Radiodifusão Sonora em Freqüência Modulada, o "RTFM", Resolução ANATEL n 67, de 12 de novembro de 1998. Tal anexo, que traz a "Especificação Técnica para a Radiotransmissão de Dados mediante Utilização do Canal Secundário de Emissora de Radiodifusão Sonora em Frequência Modulada", foi incluído pela Resolução ANATEL n 349, de 15 de setembro de 2003.

Revista de Direito, Estado e Telecomunicações, v. 2, n. 1, p. 213-230 (2010)

DOI: https://doi.org/10.26512/lstr.v2i1.21689 
congestionamentos. O RDS-TMC, que é silencioso e não interfere de forma alguma na programação principal, pois transita no canal secundário de dados, pode ajudar a fidelizar o ouvinte, interessado nas informações de trânsito. Quinto, mas não menos importante, além de não haver qualquer impedimento técnico-legal, pelo contrário, é até explicitamente previsto nos regulamentos, como veremos a seguir. ${ }^{5}$

\section{O Canal Secundário de Dados (RDS) das rádios FM}

$O$ canal principal do serviço de radiodifusão, aquele que ouvimos normalmente no receptor (ou, tecnicamente, o que ocupa de $50 \mathrm{~Hz}$ a $15 \mathrm{kHz}$ da faixa-base do canal de FM, logicamente incluído o estéreo) ${ }^{6}$, é de recepção aberta, livre e gratuita; já o canal secundário [de dados] não sofre as mesmas restrições. É um pequeno espaço ocioso, uma "sobrinha", que se pode utilizar desde que respeitados os critérios e limitações de uso do espectro que estão no Regulamento Técnico de FM (RTFM, item 3.2.9). Em outras palavras, basta que se respeite a máscara de emissão de espúrios e que não cause interferência objetável nos demais serviços. ${ }^{7}$

Além do RTFM, é importante o que diz a Portaria $\mathrm{n}^{\circ} 374$, de 15 de setembro 1992, do MTC - Secretaria Nacional de Comunicações que "dispõe de uso adequado do canal secundário de emissora em freqüência modulada":

2. Toda permissionária do Serviço de Radiodifusão Sonora em Frequência Modulada poderá usar o canal secundário correspondente, sem necessidade de autorização adicional, para executar serviços de telecomunicações.

5"RDS-TMC, Canal de Mensagens de Trânsito" (GUTERRES, 2009) ${ }^{6}$ RTFM, item 2.2, Termos Específicos: "Sinal Principal - É a informação correspondente à soma dos sinais provenientes dos canais esquerdo e direito (direito + esquerdo), ou que, em caso de transmissão monofônica, contenha o áudio da emissora", "Canal Principal - É a faixa de frequências de 50 a $15.000 \mathrm{~Hz}$ da faixabase" e "Canais Secundários - São aqueles inseridos na faixa-base, com frequência instantânea entre 20 e $99 \mathrm{kHz}$ para operação em monofonia e a partir de $55 \mathrm{kHz}$ quando em estereofonia."

${ }^{7} \mathrm{O}$ RTFM define, também no item 2.2, Interferência Objetável como "a interferência causada por um sinal excedendo o campo máximo permissível no contorno protegido de uma estação (...)" 
Ou seja, esse pequeno espaço ocioso dentro do canal do Serviço de Radiodifusão Sonora em Frequência Modulada pode ser utilizado pela permissionária para prestar um Serviço de Telecomunicação. ${ }^{8}$ E mais, a portaria traz expressões como "contratar livremente" e "autorização automática". 9

Entretanto os radiodifusores normalmente utilizam o canal secundário apenas para atividades simples como transmitir o nome da emissora, música, intérprete e mensagens de texto que aparecem no visor do receptor. São possíveis, todavia, muitas outras funcionalidades ${ }^{10}$, escassamente exploradas, como informações de sintonização, mudança automática de estação, alertas ${ }^{11}$, canais adicionais de áudio da própria emissora etc. Podese também explorar comercialmente da simples publicidade até aplicações específicas dedicadas, como o controle de letreiros de mensagens espalhados pelas cidades, rastreamento de veículos (enviar códigos de bloqueio para veículos roubados), bem como aplicações educacionais/culturais como o que ocorre nos EUA, em que existem

${ }^{8}$ Radiodifusão é Telecomunicação, mas Serviço de Radiodifusão não é Serviço de Telecomunicação - são definições políticas, não técnicas, que variam muito de Estado para Estado e ao longo do tempo. Sobre o assunto, visite "Telecomunicações, serviços de telecomunicação e serviços de Radiodifusão" (GRECO, 2007). Ainda, sobre o pandemônio que é a regulamentação brasileira dos serviços de radiodifusão, consultar "Serviços públicos de radiodifusão? Incoerência, insuficiências e contradições na regulamentação infraconstitucional" (WIMMER e PIERANTI, 2008).

${ }^{9}$ Portaria MTC-SNC no 374/92: "3. O interessado em executar serviços de telecomunicações em canal secundário de emissora em frequência modulada deverá contratar, livremente, com entidade permissionária do Serviço de Radiodifusão Sonora em Frequência Modulada, a utilização deste canal" e "5. É automática a autorização para execução de serviços de telecomunicações utilizando canal secundário de emissora em frequência modulada, observadas as disposições desta Portaria." Atentar para o fato de ser essa Portaria anterior à Lei Geral de Telecomunicações, de 1997.

${ }^{10}$ Todas muito bem documentadas no Anexo V do RTFM.

${ }^{11} \mathrm{Em}$ uma emergência é possível, por exemplo, enviar um comando para que o rádio receptor pare o que estiver fazendo, mesmo no modo $\mathrm{CD}$ ou MP3, aumente o volume e sintonize em uma determinada estação que esteja transmitindo informações críticas. 
diversas rádios públicas que fazem serviços comunitários de leitura de livros para deficientes visuais (áudio secundário) e auditivos (teletexto). O TMC, o Canal de Mensagens de Trânsito, é mais uma das muitas aplicações possíveis.

Tecnicamente, o RDS (Radio Data System) é a padronização da utilização do canal secundário de $\operatorname{dados}^{12}$ das emissoras de $\mathrm{FM}$, não o espaço (espectro radioelétrico) ocioso na faixa-base. Porém, apesar de ser uma impropriedade tratá-los por sinônimos, são tão indissociáveis que é possível referir-se tanto a um quanto ao outro usando qualquer um dos termos. ${ }^{13}$ Ele foi adaptado ${ }^{14}$ e incluído no RTFM no final de 2003, enquanto que o TMC, uma das aplicações do RDS, por ser muito complexo e além do escopo do trabalho desenvolvido na época, ficou apenas previsto no RTFM, aguardando regulamentação futura: é exatamente isto que está sendo feito no momento.

${ }^{12}$ No espectro, nada mais é do que uma portadora em $57 \mathrm{kHz}$ (junto do terceiro harmônico da portadora principal de FM, e por isso não causa interferência) de aproximadamente de 1,2 kbps, que parece pouco, mas já é mais do que suficiente para a maioria das aplicações. Se necessário, principalmente para as ODA (Aplicações Abertas de Dados), podem ser utilizadas portadoras adicionais em qualquer lugar de 53 a $99 \mathrm{kHz}$ da banda base (modo estereofônico), de qualquer tipo de modulação (RTFM, 3.2.9.b).

${ }^{13}$ Assim o faz o RTFM, no começo do Anexo V: "O objetivo deste Anexo é estabelecer a Especificação Técnica para a Radiotransmissão de Dados mediante Utilização do Canal Secundário de Emissora de Radiodifusão Sonora em Freqüência Modulada, doravante denominada RDS, que permitirá adicionar novas aplicações ao Serviço de Radiodifusão Sonora em FM, com a implementação de funções aqui definidas."

${ }^{14}$ Adaptação da "Especificação do RDS para Radiodifusão Sonora em VHF/FM na Faixa de Freqüências de 87,5 a 108,0 MHZ", EM 50067, do Comitê Europeu de Padronização Eletrotécnica - CENELEC, mais tarde atualizado para a IEC 62106:2000. 


\section{Regulamentação e funcionamento do Canal de Mensagens de Trânsito (TMC)}

O RDS-TMC surge como ideia por volta de 1982-6, pouco depois da especificação do RDS. Após muita discussão, entre 1992 e 1994 vários países europeus iniciaram testes de campo dos primeiros protótipos. Os resultados foram promissores e três anos depois serviços (ainda em caráter experimental) entram em operação na Alemanha, França e Inglaterra, seguidos posteriormente por outros países europeus. Num esforço coletivo, tudo o que se conseguiu foi reunido em três normas técnicas ISO, publicadas em 2003. A partir desse momento, principalmente na fase 2004-2007, o sistema tem uma grande expansão ${ }^{15}$ não apenas na Europa, mas nos EUA, Japão, Austrália, dentre outros. Foi incluída também uma quarta norma, sobre criptografia e acesso condicionado, em 2006.

Quem administra hoje essas quatro normas ISO é a Traveller Information Services Association, TISA ${ }^{16}$, criada pela junção, no fim de 2007, do Forum RDS-TMC (que elaborou as normas) e da Traffic Protocol Experts Group, TPEG (grupo especializado em normas de trânsito).

No Brasil o mesmo grupo que trabalhou na adaptação da norma do RDS (incluído no RTFM em 2003, como já mencionado), mais algumas adições importantes como ABNT, empresas de telemática, acadêmicos e especialistas, está debruçado na tropicalização das quatro normas do RDSTMC: ${ }^{17}$

- $\quad$ NBR ISO 14819-1 Codificação do Protocolo RDS-TMC (usando ALERT-C)

- NBR ISO 14819-2 Tabela de códigos de Eventos e Informações

- NBR ISO 14819-3 Tabela de referências de Localização

- NBR ISO 14819-6 Criptografia e acesso condicionado

${ }^{15}$ Sobre a evolução do RDS-TMC e os países onde é utilizado, consultar "European Experience with TMC" (KAMALSKI, 2005) e (HENDRIKS, 2009).

${ }^{16}$ Traveller Information Services Association (TISA): www.tisa.org.

${ }^{17}$ A primeira norma deve ser concluída ainda em 2009. O conjunto inteiro de normas, por sua vez, no prazo de dois anos.

Revista de Direito, Estado e Telecomunicações, v. 2, n. 1, p. 213-230 (2010)

DOI: https://doi.org/10.26512/lstr.v2i1.21689 
A primeira norma especifica como montar uma mensagem TMC (codificada pelo ALERT-C) que possa ser operacionalmente transmitida no RDS. Ao se prestar atenção em qualquer notícia de acidente de trânsito, repara-se que há sempre duas informações principais: LOCAL e EVENTO, podendo aparecer também alguns dados complementares. No caso do ALERT-C, são estes os dados codificados na mensagem:

$$
\begin{gathered}
\text { LOCALIZAČÃO + EVENTO } \\
\text { + DIREÇÃO/EXTENSÃO + DURAÇÃO + DESVIO }
\end{gathered}
$$

A segunda norma trata da Tabela de Eventos, que tem códigos para acidentes, congestionamentos, obras, desvios e muitos mais, enquanto que a terceira, da Tabela de Localizações, destinada à codificação de ruas, avenidas, estradas, acessos, anéis viários, cruzamentos etc. O que o sistema conjunto faz é montar códigos de localização/evento - trabalho especificado na primeira norma - a partir de tabelas padronizadas contidas na segunda e terceira normas compartilhadas entre provedores/receptores. ${ }^{18}$

O provedor de informações e os receptores dispõem das mesmas tabelas. Assim, uma informação do tipo "BR 020, sentido Brasília, trecho Sobradinho-Planaltina, acidente na pista $-4 \mathrm{~km}$ de congestionamento" pode ser transmitida como um simples código compacto, digamos algo como "3110142", diminuindo-se de quase cem para apenas sete caracteres! E, como são transmitidos apenas códigos, o receptor pode apresentar as informações em qualquer idioma, bastando que promova a conversão interna, bem como ainda pode filtrar os dados recebidos para apenas trabalhar com os relevantes para o seu percurso. ${ }^{19}$

E é justamente aí, nas tabelas de códigos de localizações e eventos, nas quais fica concentrada a inteligência do sistema, que está a chave para a implementação do RDS-TMC: quem cria, atualiza e administra essas tabelas?

${ }^{18}$ Para mais detalhes, "O que é TMC?" (BARBOSA, 2009) e "TMC - Conceito, Aplicações e Benefícios no Planejamento de Percurso" (GANDELMAN e PEDROSO, 2009).

19“RDS-TMC, Canal de Mensagens de Trânsito" (GUTERRES, 2009).

Revista de Direito, Estado e Telecomunicações, v. 2, n. 1, p. 213-230 (2010) 


\section{A implantação do RDS-TMC}

Apenas a título de comparação, em praticamente toda a Europa as tabelas são produzidas pelo governo e são livres, com exceção da Inglaterra. Nos EUA e Japão as tabelas são privadas. Na Europa, onde a radiodifusão pública tem força, há um viés mais social. Na Alemanha, as rádios e TV públicas têm obrigação legal de transmitir o canal de mensagens de trânsito. Nos EUA, Inglaterra, Japão e Austrália, a aplicação é muito mais voltada para a exploração comercial, em conjunto com diversos serviços adicionais como rastreamento de veículos, logística, informações turísticas, dentre outros. Todavia, a opção por tabelas livres e gratuitas não impede a exploração comercial do serviço. Na Alemanha e na França também existem serviços comerciais de TMC, que apostam nesses 'extras' como diferencial para conseguir assinantes.

Aliás, quanto à implantação na Europa, existe uma boa fonte de referência, o EPISODE Project ${ }^{20}$, banco de dados sobre pesquisa, desenvolvimento e implementação do RDS-TMC que envolve radiodifusores, operadores de rede, prestadores de serviço e fabricantes de equipamentos. Além de concentrar a regulamentação do setor e recomendações internacionais, glossário e fórum de discussão, traz informações sobre a implementação do RDS-TMC em mais de uma dezena de países europeus.

Para a compreensão do RDS-TMC, recomenda-se visitar o sítio eletrônico das dezenas de prestadores de serviço que oferecem o Canal de Mensagens de Trânsito ao redor do mundo e verificar como montaram suas cadeias de informação (TTI), como administram seus sistemas, o modelo de negócio implementado, o envolvimento dos órgãos públicos e as projeções mercadológicas do segmento. Os mais importantes prestadores de TMC, por país, são:

${ }^{20}$ EPISODE, European Pre-operational Implementation Survey $\boldsymbol{O}$ f further Development and Evaluation of RDS-TMC (Broadcast Sector), disponível em http://www.rds.org.uk/episode/episode.htm. Acessado em outubro de 2009. 
- Austrália: Intelematics (SUNA Traffic Channel, http://www.intelematics.com.au/), Sentinel Content Pty Limited (usa GPRS no lugar do RDS, http://www.scontent.com.au/).

- Áustria: ORF (Austrian Broadcasting, http://orf.at/), estatal, serviço livre e gratuito.

- Alemanha: TMCPro (T-Mobile International, www.t-traffic.de/), serviço pago e criptografado, além do serviço público e aberto de dez radiodifusoras estatais. As tabelas de localização, organizadas pela Bundesanstalt für Straßenwesen, têm quase 35 mil entradas, e estão entre as mais completas.

- Bélgica: são quatro prestadores de TMC, todos abertos, TMOBILIS, TIC-VL, 4FMTMC e RTBF. As tabelas são administradas por uma consultoria especializada em engenharia de trânsito, a Tritel (www.tritel.be).

- Dinamarca: serviço livre e gratuito, transmitido pela estatal Danmarks Radio, administrado pelo próprio DRD (Diretório Dinamarquês de Estradas, www.roaddirectorate.dk).

- Espanha: Radio Nacional da Espanha (www.rne.es/), com tabelas da DGT (Dirección General de Tráfico, www.dgt.es).

- Estados Unidos e Canadá: Sirius/XM por meio de rádio por satélite, Navteq Traffic (Traffic.com, www.traffic.com) por RDS, HD e rede celular (o aplicativo para iPhone está fazendo bastante sucesso); já a TTN (Total Traffic Network, www.totaltraffic.com) cobre 77 cidades norte-americanas e três canadenses. Todos os serviços são pagos.

- Finlândia: serviço comercial, Destia (www.destia.fi/tmc/english), com tabelas estatais providenciadas pela FINNRA (Finnish Road Administration).

- França: V-Traffic (Mediamobile, www.mediamobile.com), o maior, com cerca de 60.000 assinantes, ViaMichelin e Carte Blanche são pagos, mas não encriptados. AREA, ASF, ATMB, Cofiroute, ESCOTA, SANEF, SAPN, SAPRR, SFTRF e SMTPC são abertos. As tabelas são governamentais, administradas pela SETRA (Service D'Etudes Techniques des Routes et Autoroutes, www.setra.developpementdurable.gouv.fr/).

- Holanda: no momento o serviço TMC da TMC4U (www.tmc4u.nl) é aberto, mas deve passar a ser pago em breve. ViaTMC e Radio2 são outras duas opções. As tabelas são estatais, criadas pela AVV Transport Research Centre e mantidas pela TIC Nederland.

- Inglaterra: dois prestadores, iTIS Holdings (www.itisholdings.com) e RTT (RAC Trafficmaster Telematics, www.rac.co.uk/), cada um deles com suas próprias tabelas.

- Itália: desde 1998 prestado gratuita e abertamente pela estatal RAI (www.rai.it), que inclusive auxilia na administração das tabelas o CCISS (Centro Nacional de Informações de Trânsito); também está disponível o serviço por assinatura RTL/InfoBlu (www.rtl.it/). 
- México: primeiro serviço, na Cidade do México, comercial, entrando em operação agora no fim deste ano, prestado pela CCTTN (Red Total del Tránsito de Clear Channel Radio), filial do grupo estadunidense Clear Channel - Total Traffic Network (www.totaltraffic.com).

- $\quad$ Noruega: NRK, ainda em fase de testes; as tabelas vêem da Statens Vegvesen (Administração das Estradas Públicas da Noruega, www.vegvesen.no/).

- República Tcheca: três prestadores, serviço aberto, TIC PRAGUE, TELEASSIST e JSDI. Tabelas administradas pela CEDA (www.ceda.cz), empresa especialmente criada pelo governo.

- Suécia: atualmente um serviço está disponível por meio da Vägverket (Administração das Estradas Suecas, www.vv.se/), que também se encarrega das tabelas, mas passará a serviço por assinaturas explorado pela Destia, a mesma da Finlândia.

- Suíça: serviço disponível pela SRG SSR (Corporação de Radiodifusores Suíços), com tabelas criadas pela $B+S$ Ingenieur (Bundesamt fuer Strassen), mas administradas pela FEDRO (Escritório Federal de Estradas, Autoridade Federal das Estradas da Suíça, www.astra.admin.ch).

Quanto ao Brasil, o que aconteceria se houvesse uma ação pública que fomentasse a implantação do RDS-TMC pela produção e manutenção das tabelas e preparo dos centros de informações (CET/CIT, polícias, bombeiros, SSP) para prontificar a distribuição de eventos de trânsito para os produtores de programação TMC? Seria suficiente para exigir como contraprestação social que as informações principais/básicas (como acidentes e emergências) fossem distribuídos livre e gratuitamente, ou os custos da infra-estrutura mesmo assim impossibilitariam tal feito?

\section{Uma implementação híbrida brasileira do RDS-TMC}

É interessante, para os radiodifusores, que todos recebam informações de trânsito, mesmo que apenas as mais simples, pois isso mantém os ouvintes sintonizados. Para o Estado, o canal representa uma possibilidade sem igual de melhor administrar o trânsito (e em tempo real!) e até de se comunicar com o cidadão em uma emergência. Envolvendo-se diretamente na cadeia de informação, o Estado pode melhor controlar a qualidade dos dados das tabelas e das informações distribuídas. Mesmo para os prestadores do serviço, a alternativa de um modelo híbrido, mesclando mensagens livres e abertas, pode ser muito vantajosa, pois serve de "vitrine" para um produto 
comercial "completo", traduzindo-se em um conjunto muito mais lucrativo de serviços, com logística, rastreamento, informações turísticas, entre outros, capaz, por exemplo, de traçar rotas alternativas de desvio e calcular o tempo necessário para o percurso/viagem, enquanto as mensagens abertas apenas apontam os incidentes mais significativos.

Mas há mais a se considerar. Mesmo com a facilidade de implementar a distribuição do TMC codificado para as emissoras de FM por meio da internet (o codificador RDS é um equipamento que normalmente opera ligado à rede de computadores), ainda são necessários para os eventuais prestadores de TMC muitos recursos físicos e humanos para administrar todo o processo, desde adquirir as informações, até codificá-las para, por fim, distribuí-las.

E isso é o que justifica o modelo híbrido, nem totalmente estatal, nem totalmente privado, pois se restrito à iniciativa privada, dados os altos custos de manutenção da cadeia de informações, estará fadado a ser um serviço elitista, heterogêneo e de pequena amplitude. Da mesma forma, embora haja para o Estado o norte do interesse social, além de ser importante a participação da radiodifusão estatal, não convém prestar diretamente os serviços agregados.

Nessa linha, o Estado manteria, através de órgãos especializados das três esferas e em conjunto com a iniciativa privada, tabelas universais, de acesso livre, e ainda auxiliaria os provedores de programação RDS-TMC na obtenção dos incidentes de trânsito e problemas climáticos por intermédio do preparo dos centros de informação como CET/CIT municipais, SSP, polícias, bombeiros, dentre outros, enquanto que, na outra via, os prestadores de serviços disponibilizariam, de forma aberta e gratuita, as informações básicas, os eventos principais, ficando livres para explorar, como bem entenderem, o sistema de todas as outras formas. A remuneração adviria de assinaturas ou seria incluído no preço final do terminal receptor.

\section{Os (imensos) desafios regulatórios}

Para que a parceria entre o Estado e a iniciativa privada funcione adequadamente e prospere, é necessário ressaltar algumas ponderações: 


\section{Autocontrole}

Como primeiro ponto, as normas técnicas do RDS-TMC serão normas ISO NBR, editadas pela ABNT, após o devido processo de aprovação, que prevê consulta pública e uma série de estágios de revisão. As porções do RDS-TMC que tratam do próprio RDS e a sua ocupação espectral - regras de operação para que não haja interferência objetável entre os serviços - já estão no RTFM da ANATEL. Mas todo o restante, de natureza eminentemente técnica/especializada e que seja inofensivo ao espectro e aos direitos dos consumidores, ou à viabilidade e segurança do serviço, e a premente necessidade de flexibilidade da atualização das normas justificam uma limitação na intervenção normativa do Estado regulador em prol de um fórum de normalização misto e simplificado. ${ }^{21}$

Propõe-se uma regulação cooperativa, não-coercitiva, na qual o ente regulador atua como supervisor e mediador; um espaço neutro de diálogo para discutir e traçar metas coletivas de desenvolvimento do sistema ${ }^{22}$. Engessá-las em regulamentos impositivos e de difícil atualização seria improdutivo, e até prejudicial.

\section{Regulação de conteúdo}

Quanto àquilo que escapa dos pontos acima, isto é, o necessário para proteger o consumidor/usuário, prevenir o mau uso do sistema e direcionar a sua aplicação para extrair benefícios para a sociedade, o TMC é 'canal de mensagens', um conjunto completo, integrado e auto-suficiente de informações de interesses e finalidades específicas transitando de forma continuada num meio de telecomunicação. Como tal, ele deve ser regulado, independente do meio em que trafegue.

São muitos os serviços de interesse econômico geral que podem ser prestados pelos mais diversos canais de informação, como índices da bolsa

${ }^{21} \mathrm{O}$ desenvolvimento técnico da TV Digital acontece em um fórum, e as normas são produzidas na ABNT. Aliás, as Normas ABNT NBR 15606-2 V2 e ABNT NBR 15601 a 15607 foram recentemente aprovadas nas recomendações da UIT para televisão digital (middleware).

${ }^{22}$ Uma análise interessante do impacto das experiências "desregularizadoras", em especial da tendência europeia batizada como meta-regulation, assemelhada à ideia aqui defendida, está em "Características e oportunidades da desregulação: a busca por um novo modelo de atuação estatal" (LAENDER, 2009).

Revista de Direito, Estado e Telecomunicações, v. 2, n. 1, p. 213-230 (2010)

DOI: https://doi.org/10.26512/lstr.v2i1.21689 
de valores, notícias, previsão do tempo, entretenimento, cultura e muitos outros. Em regra, não se controla conteúdo de um canal. Todavia, alguns deles, como os que dão acesso aos serviços bancários, por exemplo, ou egoverno também, requerem um nível maior de controle dada sua natureza, finalidade e importância social. O TMC é um deles pois, sendo infraestrutura crítica $^{23}$, se mal usado, pode causar grandes prejuízos e até mesmo tragédias. Pensando em termos de segurança pública e defesa nacional, pode-se até restringir a propriedade desse canal, tal qual ocorre na radiodifusão, e criar imposições de livre e irrestrito acesso dos órgãos públicos em determinadas situações, tais como calamidades públicas. De qualquer forma, tomando-se como base sua natureza e relevância social, o TMC requer acompanhamento qualificado.

\section{Dimensão objetiva do direito fundamental à informação}

A Constituição Federal de 1988, art. 5, XXXIII prevê que "todos têm direito a receber dos órgãos públicos informações de seu interesse particular, ou de interesse coletivo ou geral (...)".Um dos alicerces do Estado Democrático de Direito, o direito à informação tem uma tripla faceta: (1) o direito de informar, (2) o direito de se informar e (3) o direito de ser informado. "O direito de ser informado tem por conteúdo o recebimento de informações fidedignas do Estado sobre quaisquer fatos de interesse público, bem como o pleno acesso a elementos mantidos em arquivos públicos, de interesse público ou particular. O Estado é devedor da prestação de comunicar aos cidadãos sobre todos os fatos relevantes que são do seu domínio, sem prejuízo de franquear acesso a quem buscar outros elementos. É o direito à verdade, que obriga também aos meios de comunicação, os quais devem prestar informações de interesse público, desde que verossímeis e decorrentes de apuração responsável." ${ }^{24}$ Quais seriam, portanto, as condições que justificam a ação positiva do Estado, dever de tomar medidas concretas visando à promoção, desenvolvimento e efetivação do direito de informação?

${ }^{23}$ Consultar o trabalho intitulado "Infra-estrutura Crítica de Radiodifusão" (SOUZA, 2009).

${ }^{24}$ Verbete Informação (direito à) do "Dicionário de Direitos Humanos" (WELCHERT, 2009). 
Se a tecnologia permite a transmissão de informações que podem melhorar as condições do trânsito caótico nas grandes cidades ${ }^{25}$, diminuir o desperdício de recursos, melhorar a qualidade do ar e a saúde da cidade, preservar e otimizar a infraestrutura, facilitar o escoamento do transporte coletivo e o funcionamento dos serviços de segurança pública, e ainda servir de apoio em momentos críticos e emergenciais, ela responde à realização da cidadania, que não se restringe ao clássico gozo de direitos civis e políticos, mas incorpora em seu conceito o significado de uma cidadania coletiva, de ampliação de direitos ligados à saúde coletiva, ao bem-estar, à qualidade de vida, ao não desperdício de recursos humanos e naturais, à preservação dos bens públicos e ao desenvolvimento urbano.

Se existem grupos privados interessados em prestar um serviço em cooperação com o poder público, em um modelo viável e colaborativo já utilizado com sucesso em outros países, além do interesse e apoio de radiodifusores, em especial tendo por finalidade o interesse coletivo e o bem-estar social, acreditamos, humildemente, que já estão reunidas as condições mínimas para engatilhar a dimensão objetiva do direito fundamental à informação a ser melhor desenvolvido em desenvolvimento futuro deste informe, e obter do Estado ações que, além do reconhecimento formal, trilhem o caminho para o amplo e universal usufruto de tal benefício. $^{26}$

O TMC é só uma sementinha no RDS/FM; ela é o começo de algo muito, muito maior, que, em um futuro não muito distante, estará infiltrado nos mais variados meios de comunicação para fazer parte do dia-a-dia das pessoas e mudar a forma como dirigem.

\footnotetext{
${ }^{25}$ Previsões apocalípticas podem ser encontradas em "TRÂNSITO: São Paulo vai parar em 2012? Aumento do número de veículos pode provocar colapso do trânsito da cidade em quatro anos" (ipcdigital.com, 2008).

${ }^{26}$ Uma última recomendação de leitura: "Sociedade do conhecimento e controle da informação e da comunicação" (MITTELART, 2005)
}

Revista de Direito, Estado e Telecomunicações, v. 2, n. 1, p. 213-230 (2010)

DOI: https://doi.org/10.26512/1str.v2i1.21689 


\section{Bibliografia}

BARBOSA, Ronald S. TMC - O que é isso? In: Revista da Sociedade Brasileira de Engenharia de Televisão. Ano XXI, no 108. Jul./Ago. de 2009. p. 27-30.

BRASIL. Portaria MTC n $^{\mathbf{3}}$ 374/92, de 15 de setembro de 1992, que "dispõe de uso adequado do canal secundário de emissora em frequência modulada". Ministério dos Transportes e das Comunicações, Secretaria Nacional de Comunicações. Diário Oficial da União. Brasília.

BRASIL. Resolução ANATEL $\mathbf{n}^{\circ}$ 67, de 12 de novembro de 1998, que "aprova o Regulamento Técnico para Emissoras de Radiodifusão Sonora em Frequência Modulada". Agência Nacional de Telecomunicações. Brasília.

BRASIL. Resolução ANATEL no 349, de 25 de setembro de 2003, que, entre outras providências, inclui o Anexo V que traz a "Especificação Técnica para a Radiotransmissão de Dados mediante Utilização do Canal Secundário de Emissora de Radiodifusão Sonora em Frequência Modulada". Agência Nacional de Telecomunicações. Brasília.

CARVALHO, André de S. Aplicação do TMC no Processo Estratégico dos Sistemas Inteligentes de Transportes (ITS). $\mathrm{XI}^{\circ}$ Seminário sobre a Eletro-Eletrônica Aplicada a Mobilidade. Associação Brasileira de Engenharia Automotiva - AEA. São Paulo, 28 Maio 2009.

GRECO, Rodrigo A. Telecomunicações, Serviços de Telecomunicação e Serviços de Radiodifusão. In: Concurso Nacional de Monografias da ABDI sobre Direito de Informática e telecomunicações: 2002 a 2004. São Paulo, ABDI: 2007.

GANDELMAN, Gilberto e PEDROSO, Rubens C. TMC - Conceito, Aplicações e Benefícios no Planejamento de Percurso. $\mathrm{XI}^{\circ}$ Seminário sobre a Eletro-Eletrônica Aplicada a Mobilidade. Associação Brasileira de Engenharia Automotiva - AEA. São Paulo, 28 Maio 2009.

GUTERRES, Egon C. RDS-TMC, Canal de Mensagens de Trânsito. Palestra proferida no Congresso SET 2009. Sociedade Brasileira de Engenharia de Televisão. 25 a 28 Ago. 2009.

HENDRIKS, Teun. Traveller Information Services Association. Home of the TMC and TPEG standards. Palestra proferida no ETSI workshop on ITS. França: Sophia Antipolis, 04 Fev. 2009. Versão eletrônica disponível em: http://portal.etsi.org/docbox/Workshop/2009/200902__TSWORKSHOP/TISA_Hendricks.pdf. Acesso em: 21 de outubro de 2009.

IPCDIGITAL.COM. TRÂNSITO: São Paulo vai parar em 2012? Aumento do número de veículos pode provocar colapso do trânsito da 
cidade em quatro anos. Disponível em: http://www.ipcdigital.com/br/Noticias/Brasil/TRANSIT0-Sao-Paulo-vai-parar-em-2012. Acesso em: 31 de outubro de 2009.

KAMALSKI, Theo. European Experience with TMC. TMC Workshop. Alemanha, 5 de abril de 2005. Disponível em: http://www.ertico.com/download/dynasty documents/workshop\%20april\%2005/SVDO-Kamalski.pdf. Acesso em: 18 de outubro de 2009.

LAENDER, Gabriel B. Características e oportunidades da desregulação: a busca por um novo modelo de atuação estatal. Revista de Direito, Estado e Telecomunicações, v. 1, n. 1, p. 181-202. (2009)

MITTELART, Armand. Sociedade do conhecimento e controle da informação e da comunicação. V Encontro Latino de Economia Política da Informação, Comunicação e Cultura. Salvador, 9 a 11 Nov. 2005.

SOUZA, Maria Regina de Felice. Infra-estrutura Crítica de Radiodifusão. Palestra proferida no Congresso SET 2009. Sociedade Brasileira de Engenharia de Televisão. 25 a 28 Ago. 2009.

VEJA.com: Trânsito. O impacto do caos nas ruas. Disponível em: http://veja.abril.com.brlidade/exclusivo/transito/contextol.html. Acesso em: 17 de outubro de 2009.

WELCHERT, Marlon A. Informação (direito à). Dicionário de Direitos Humanos. Disponível em: http://www.esmpu.gov.br/dicionario/tiki-index.php?page=Informação. Acesso em: 25 de outubro de 2009.

WIMMER, Miriam e PIERANTI, Octavio P. Serviços de radiodifusão? Incoerências, insuficiências e contradições na regulamentação infraconstitucional. In: Revista de Economía Política de las Tecnologías de la Información y Comunicación. Vol. XI, n. 1, jan. - abr. de 2009. 